His friendships were keen and constant; slow to form an affection, but once formed they were warm and enduring. $\mathrm{He}$ sought his friendships among the good, the diligent and the lovers of nature. By us who knew him best his loss is most keenly felt, and the botanical world is the loser not only of the talent he had exhibited, but, prospectively, of the greater things which his short career promised.

Helena, Montana.

\title{
Enumeration of the Kansas mosses.
}

\section{F. RENAULD AND J. CARDOT.}

Kansas, and chiefly the central part of this state, is certainly one of the regions the most destitute of mosses of any part of the United States: the atmospheric dryness, a climate extensively variable and liable to extremes of temperature and the extension of cultivated and meadow lands are the causes of the poverty of this bryological flora. For a long time it was a common belief that this land was almost entirely destitute of mosses; but it has been proved by recent researches that such is not the case, and if the moss-flora of this country is very poor in comparison with that of other states it includes, however, a relatively important number of species. The most part of these, however, grow in meagre, stunted and sterile specimens, which often makes their determination very difficult.

In 1884-85-86 Mr. Eugene A. Rau published in the Bulletin of the Washburn College Laboratory of Natural History four contributions to the knowledge of Kansas mosses, including a total of fifty-three species, collected chiefly by Prof. F. W. Cragin, Miss Mara Becker and Mr. Joseph Henry. The last,
who who died on October I 2, I 887, aged more than 74 years, sent us during the year 1885 and until his death, all the species he had collected in Saline county, and by the study of this collection we are able to add nearly forty species to those previously reported by Mr. Rau.

The present catalogue includes all the mosses recorded in the four lists published by this bryologist and all those Vol. XVII,-No. 3. 
main doubtful, and some specimens, too incomplete to allow any determination, have been omitted.

All the species of which we have received specimens are indicated by the affirmative mark $(!)$; the asterisk $(*)$ indicates those which are not recorded in Mr. Rau's contributions. The geographical names are those of counties unless otherwise noted.

*Sphagnum molle Sulliv. - Salıne, a very young sterile form (Henry)!

*Micromitrium sp?-Too young for determination. Saline (Henry)!

Ephemerum spinulosum BS.- Saline (Henry)!

* papillosum Aust.-Saline (Henry)!

Phascum cuspidatum Schreb. (?)-Saline, sterile (Henry)!

* var. piliferum BS.-Saline (Henry)!

*Microbryum Floerkeanum Sch. var. Henrici Ren. \& CARD. Bot. Gaz. XIV. gI. (I889). Saline (Henry)!

*Pleuridium Bolanderi C. Muell.(?)-Saline, sterile (Henry)!

*Archidium Hallii Aust. - Saline (Henry)!

*Astomum crispum HPE.-Saline (Henry)!

* Sullivantii ScH.-Saline (Henry)!

Weisia viridula BRID.-City of Topeka (Field). Shawnee (Becker, Cragin).

Wyandotte (Bennett). Saline, common (Henry)! var. stenocarpa C. Muell.-Verdigris valley, Wilson (Cragin).

Dicranella varia S $\mathrm{cH}$.-City of Topeka (Cragin). Shawnee (Becker). Saline, common (Henry)!

heteromalla ScH.-Saline (Henry)! Also a sterile form, with shorter leaves; rather doubtful. Saline (Henry)!

Dicranum scoparium Hedw.-Labette (Nelson). Saline, sterile form with leaves

* often broken at point (Henry)!
*Campylopus Henrici REN. \& CARD. Bot. Gaz. XIII (1888), I 97 pl. XIV.-Saline, Fissidens sterile (Henry)!

Fissidens bryoides Hedw. - Saline (Henry)!

* Bambergeri Sch.-Saline, sterile (Henry)! New to North America.

* obtusifolius WiLs.-Saline, sterile (Henry)!

var. Kansanus REN. \& CARD. Bot. Gaz. XV (189o), 40.Saline (Henry)!

osmundoides Hedw.-Brown (Becker)

Ceratodon purpureus BRID, - City of Topeka (Field). Ford (Cragin). Saline, a

*Pharomitrium subsessile ScH.-Saline (Henry)! with the young form named by Austin $P$. exiguum.

*Didymodon species nova ?-Saline (Henry)!

Leptotrichum pallidum HPE.-Saline, sterile form with leaves often broken at point (Henry)! Labette, a doubtful sterile form (Newlon). vaginans ScH.-Saline (Henry).

*Trichostomum crispulum BRUCH.-Saline, common; several sterile forms (Henry)!

*Desmatodon arenacens S. \& L.-Saline, sterile (Henry)!

* $\quad$ plinthobius S. \& L. (?).-Saline, sterile (Henry)!-Owing to the absence of fructification, it is almost impossible to decide whether these specimens belong to Desmatodon plinthobius,

Barbula Henrici Rau, Bull. of the Washb. Coll. Lab. I (1886), 172.- Saline,
sterile (Henry)! We suspect sterile (Henry)! We suspect this plant, known only in sterile state, to be referable to Pharomitrium subsessile.

unguiculata Hedw.-City of Topeka, Wilson (Cragin). Brown (Becker). Saline, common and very variable, but generally sterile (Henry)! 
* fallax Hedw.-Saline , sterile (Henry)!

convoluta Hedw.-Saline, sterile (Henry)!

caespitosa ScHw.-Wabaunsee (Baldwin). Saline (Henry).

Grimmia apocarpa Hedw. - Saline sterile (Henry)!

calyptrata Ноок. - Saline (Henrı).

* leucophæa GREv. - Saline, common, but sterile (Henry)!

* Olneyi Sulliv. (?). - Saline, a sterile stunted form (Henry)!

*Hedwigia ciliata EHRH.-Saline, a sterile and very stunted form, with leaves not piliferous (Henry)!

* Coscinodon Wrightii Sulliv.-Saline (Henry)!

* Renauldi CARD. Bot. Gaz. XV (IS9O), 4I, pl. VI, B.-Saline (Henry)!

Orthotrichum strangulatum Beauv.-Saline (Henry)!

Pyramidula tetragona BRID.-Saline (Henry).

Physcomitrium pyriforme BRID.-City of Topeka (Fields, Cragin). Brown (Becker). Labette (Newlon).

* acuminatum BS.-Long Island, Phillipps county (Hatcher.)

* turbinatum C. Muell.(?)-Saline, sterile (Henry)!

Funaria hygrometrica Hedw. - City of Topeka (Fields, Cragin). Labette

(Newlon). Saline (Henry)!
* Bartramia pomiformis Hedw. - Labette (Newolon.)

* radicalis BEAuv. - Saline, sterile (Henry)!

"Philonotis Muehlenbergii BRID. - Saline, not uncommon but sterile (Henry)!

marchica BRID. - Saline (Henry). Reported by Rau, but perhaps referable to the last.

Webera annotina ScHw.-Shawnee (Becker).

albicans ScH.-Brown (Becker). Wilson (Cragin). Saline, sterile (Henry)!

Bryum argenteum L.-City of Topeka (Fields). Kansas River, Shawnee,

* Wilson (Cragin.) Saline sterile (Henry)!

caespiticium L.- Saline, not uncommon, but sterile (Henry!)

bimum Schreb.-City of Topeka (Cragin), Saline (Henry).-Perhaps referable to the following.

*

pseudotriquetrum ScHw.-Saline, common, but sterile (Henry)!

Ontariense KINDB. Bull. of the Torr. Bot. Club, XVI (1889), 96.-

Saline, a few sterile stems (Henry)!
Mnium cuspidatum Hedw.-City of Topeka, common (Fields). Shawnee (Becker, Cragin). Wabaunsee (Baldwin). Brown (Becker). Labette (Nervlon). Wyandotte (Bennett). Saline, common (Henry)!

* affine BLAND.-Shawnee (Cragin). Saline (Henry). var. elatum BS.-Saline, sterile (Henry)!
Atrichum undulatum Beauv. - Saline (Henry), reported by Rau, but probably

* referable to the following variety.

var. altecristatum REN. \& CARD. Bot. Gaz. XV (I890). 58.Saline (Henry)!

angustatum BS, - Town of Tecumseh (Cragin). Shawnee (Becker, Cragin). Labette (Newlon). Wyandotte(Bennett). Saline (Henry).

*

* Fabronia xanthopelma Leso. \& James. - Saline, not uncommon (Henry)!

Theliania octoblepharis ScHw. - Saline, sterile (Henry)!

(Becker). Leskea polycarpa

(Cragin). Shawnee,

Brown (Becker). Wyandotte (Bennett). Saline, common, several forms (Henry) ;

Austini Sullrv.-Saline (Henry)!
Anomodon rostratus ScH,-Wabaunsee (Baldwin). Verdigris valley, Wilson (Cragin.) Saline, sterile (Henry)!

attenuatus HARTM.- - Wyandotte (Bennett.)

obtusifolius BS. - City of Topeka (Fields). Brown (Becker). Saline (Henry)! 
Pylaisia intricata BS. - Jefferson (Cragin). Saline (Henry)!

*Cylindrothecium cladorrhizans ScH.-Saline (Henry)! with a form much resembling $C$. brevisetum by its stems and branches less compressed, and its pedicel shorter.

seductrix Sulliv. - Shawnee (Cragin, Becker). Wabaunsee (Baldwin). Brown (Becker).

* compressum BS. - Saline (Henry)!

*Climacium dendroides W×B. \& MoHr. - Saline sterile (Henry)!

*Thuidium recognitum LindB. ?' Th. delicatulum LindB.?-Saline, sterile (Henry)!

Brachythecium læatum BS. - Shawnee (Becker). Wabaunsee (Baldroin). Labette (Newlon). Saline, sterile (Henry)!

*

var. dentatum Leso \& James. - Saline, sterile (Henry)! acuminatum (Beauv).-City of Topeka (Fields). Shawnee, Brown (Becker). Wilson (Cragin). Saline, common, but sterile (Henry)!

rivulare BS. (?).-Saline (Henry). Wyandotte (Bennett). plumosum BS. (?).-City of Topeka (Fields). Saline, doubtful (Henry.)

Eurhynchium strigosum BS. - Wabaunsee (Baldwin).

* praelongum BS.-Saline, sterile (Henry)!-Lesquereux and James, in the "Manual of the Mosses of North America," p. 353, state that "the true Hypnum praelongum has scarcely been found on this continent," where its place is supplied by the $H$. hians Hedw. However, all the specimens we have hitherto seen from North Amèrica are found quite identical with the European forms of $H$. praelongum, their leaves being serrulate all around, a character which does not agree with description of $H$. hians.

hians (Hedw.)-Shawnee (Becker, Cragin).

Rhynchostegium serrulatum (HEDw.) - City of Topeka (Fields) Wabaunsee (Baldwin). Jefferson (Cragin) Saline, sterile (Henry)!

Amblystegium serpens BS. - City of Topeka, Tecumseh (Fields, Cragin). Shawnee (Becker, Cragin). Brown (Becker). Jefferson (Cragin) Saline (Henry)!

* varium (Beauv.)-Saline, common (Henry)! porphyrrhizum ScH.-Saline, (Henry)! Seems to be identical with $A$. hygrophilum Sch. adnatum (Hedw).-Saline, sterile (Henry)! riparium BS.-Brown (Becker). Saline (Henry)!

var. cariosum Sulliv.-Saline (Henry).

var. serratum REN. \& CARD. Bot. Gaz. XIV (1889), 98.-

* Kochii Sch.-Saline (Henry)! New to North America.

Hypnum hispidulum BriD. - Shawnee (Cragin). Brown (Becker). Saline (Henry)! chrysophyllum BRID. - Labette (Nezvion). Saline, sterile (Henry)! aduncum Hedw.-Saline, sterile (Henrv)!

Surveying the whole of this bryological florula it becomes immediately evident that the most part of the species are characteristic for the flora of the middle and eastern states. As such are chiefly to be noted: Sphagnum molle, Micromitrium?, Ephemerum spinulosum, E. papillosum, Astomum Sullivantii, Fissidens obtusifolius, Pharomitrium subsessile, Leptotrichum vaginans, Desmatodon arenaceus, Grimmia Olneyi?, Orthotrichum 
strangulatum, Philonotis Muehlenbergii, Bryum Ontariense, Fabronia octoblepharis, Thelia asprella, Leskea Austini, Anomodon rostratus, A. attenuatus A. obtusifolius, Pylaisia intricata, Cylindrothecium cladorrhizans, C. seductrix, C. compressum, Brachythecium laetum, B. acuminatum, Rhynchostegium serrulatum, Amblystegium varium, A. adnatum, Hypnum hispidulum, H. chrysophyllum.

The following species belong to the flora of the southern states (Texas Louisiana, etc.) and reach here their extreme limit northward: Archidium Hallii, Desmatodon plinthobius ?, Barbula caespitosa, Physcomitrium turbinatum?, Bartramia radicalis, Atrichum xanthopelma.

Grimmia calyptrata and Coscinodon Wrightii seem more especially peculiar to the flora of the Rocky Mountains. Trichostomum crispulum and Pleuridium Bolanderi ? were hitherto only recorded from California.

Monaco, and Stenay, France.

\section{Noteworthy anatomical and physiological researches.}

\section{Ovular structure of Casuarina suberosa. ${ }^{1}$}

In this work of Treub's we have a very good example of the sensational in plant morphology. The word is not at all to be taken in a bad sense but fitly describes the altogether unsuspected results which have followed this careful investigator's examination of a group of plants of acknowledged difficulty. After discussing the insertion of the ovules and their curious displacements which have caused much discussion (see on this Baillon, Eichler, Miquel and Engler), Treub takes up the ovular structure with the following conclusions:

I. Certain large sub-epidermal cells in the young ovule are an archesporium and develop the macrospores (embryo-sacs). They lie at the summit of the nucellus and undergo a series of tangential segmentations, finally producing a thick cylinder of sporogenous tissue which, surrounded by the tapetal layer, occupies a central position in the nucellus.

2. The cells of the sporogenous layer develop tetrads of spores, of which three become absorbed, in some cases, but in

${ }^{1}$ Treub: Sur les Casuarinèes et leur place dans le system natural. Ann. Jard.
Buitenz. x. I $45-23 \mathrm{I}$. 


\section{$2 \mathrm{BHL}$ Biodiversity Heritage Library}

Renauld, Ferdinand and Cardot, Jules. 1892. "Enumeration of the Kansas Mosses." Botanical gazette 17(3), 81-85. https://doi.org/10.1086/326769.

View This Item Online: $\underline{\text { https://www.biodiversitylibrary.org/item/92733 }}$

DOI: https://doi.org/10.1086/326769

Permalink: https://www.biodiversitylibrary.org/partpdf/222127

\section{Holding Institution}

Missouri Botanical Garden, Peter H. Raven Library

\section{Sponsored by}

Missouri Botanical Garden

\section{Copyright \& Reuse}

Copyright Status: Public domain. The BHL considers that this work is no longer under copyright protection.

This document was created from content at the Biodiversity Heritage Library, the world's largest open access digital library for biodiversity literature and archives. Visit BHL at https://www.biodiversitylibrary.org. 